\title{
Increased levels of YKL-40 in patients with diabetes mellitus: a systematic review and meta-analysis
}

\author{
Wanwan Luo®, Lingmin Zhang, Lingling Sheng, Zhencheng Zhang and Zaixing Yang*
}

\begin{abstract}
Background: Diabetes mellitus (DM) could be classified as type 1 diabetes mellitus (T1DM), type 2 diabetes mellitus (T2DM), gestational diabetes mellitus (GDM) and others according to etiology and pathology. Diabetic nephropathy (DN) is one of the most serious complications of DM. YKL-40 is a marker of inflammation and some studies have indicated that DM was related with inflammation. The objective of our study is to perform a systematic review and meta-analysis to confirm the relationship between YKL-40 and DM as well as DN.

Methods: Pubmed, Embase, CNKI and Chinese wanfang databases were searched for eligible studies by two independent authors. Studies were included in this meta-analysis if they fulfilled the following inclusion criteria: (1) a study involving the role of YKL-40 in DM (or DN) designed as a case-control study or cohort study; (2) the data of serum YKL40 levels were available; (3) studies were published in English or Chinese. Finally, twenty-five studies were included in this meta-analysis.

Results: Compared with healthy controls, DM patients had significantly higher levels of YKL-40 (DM: SMD $=1.62,95 \%$ $\mathrm{Cl} 1.08$ to $2.25, \mathrm{P}=0.000 ; \mathrm{GDM}: \mathrm{SMD}=2.85,95 \% \mathrm{Cl} 1.01$ to $4.70, \mathrm{P}=0.002$ ). Additionally, DM patients with different degree of albuminuria had significantly higher levels of YKL-40 compared with healthy controls (normoalbuminuria: $\mathrm{SMD}=1.58,95 \% \mathrm{Cl} 0.59$ to $2.56, \mathrm{P}=0.002$; microalbuminuria: $\mathrm{SMD}=2.57,95 \% \mathrm{Cl} 0.92$ to $4.22, \mathrm{P}=0.002$; macroalbuminuria: $\mathrm{SMD}=2.69,95 \% \mathrm{Cl} 1.40$ to $3.98, \mathrm{P}=0.000$ ) and serum $\mathrm{YKL}-40$ levels increased with increasing severity of albuminuria among DM patients (microalbuminuria vs normoalbuminuria: $\mathrm{SMD}=1.49,95 \% \mathrm{Cl} 0.28$ to 2.71, $\mathrm{P}=0.016$; macroalbuminuria vs microalbuminuria: $\mathrm{SMD}=0.93,95 \% \mathrm{Cl} 0.34$ to $1.52, \mathrm{P}=0.002$ ).

Conclusions: Our current meta-analysis demonstrates that serum level of YKL-40 is increased in DM and positively associated with the severe degree of albuminuria. Therefore, we suggest that YKL-40 could be considered to be detected, along with other inflammatory markers, if DM, especially DN, is suspected.
\end{abstract}

Keywords: Diabetes mellitus, YKL-40, Diabetic nephropathy, Meta-analysis

\section{Background}

Diabetes mellitus (DM) is a common disease in the modern society. According to etiology and pathology, DM could be classified as type 1 diabetes mellitus (T1DM),

*Correspondence: yangzaixingdiyi@163.com

Department of Laboratory Medicine, Huangyan Hospital of Wenzhou Medical University, Taizhou First People's Hospital, Taizhou, Zhejiang, China type 2 diabetes mellitus (T2DM), gestational diabetes mellitus (GDM) and others [1]. Diabetic nephropathy (DN), defined by low estimated glomerular filtration rate $\left(<60 \mathrm{~mL} / \mathrm{min} / 1.73 \mathrm{~m}^{2}\right.$ for 3 months or more) or albuminuria (urinary albumin-to-creatinine ratio $\geq 30 \mathrm{mg} / \mathrm{g}$ ) in the setting of DM [2], is one of the most serious complications of DM. Previous epidemiological studies have indicated that $25 \%$ to $40 \%$ of patients with T1DM and $5 \%$ to $40 \%$ of patients with T2DM ultimately develop DN [3,

(c) The Author(s) 2021. This article is licensed under a Creative Commons Attribution 4.0 International License, which permits use, sharing, adaptation, distribution and reproduction in any medium or format, as long as you give appropriate credit to the original author(s) and the source, provide a link to the Creative Commons licence, and indicate if changes were made. The images or other third party material in this article are included in the article's Creative Commons licence, unless indicated otherwise in a credit line to the material. If material is not included in the article's Creative Commons licence and your intended use is not permitted by statutory regulation or exceeds the permitted use, you will need to obtain permission directly from the copyright holder. To view a copy of this licence, visit http://creativeco mmons.org/licenses/by/4.0/. The Creative Commons Public Domain Dedication waiver (http://creativecommons.org/publicdomain/ zero/1.0/) applies to the data made available in this article, unless otherwise stated in a credit line to the data. 
4]. The pathology of DM is not totally understood. Some studies have indicated that DM is related to inflammation $[5,6]$. Inflammatory markers, including interleukin (IL) 6, IL-1ßand tumor necrosis factor (TNF)- $\alpha$, were found increased in DM patients [7, 8].

YKL-40, also called human cartilage glycoprotein-39 (HCgp-39), is a $40 \mathrm{KDa}$ heparin- and chitin-binding glycoprotein [9]. In vivo, CD 16+ monocytes are a source of YKL-40 and transcription factor Sp1 plays an important role in regulating of YKL-40 [10, 11]. In addition, YKL40 is secreted by chondrocytes, synovial cells and neutrophils [9]. In vitro, YKL-40 is secreted by various cells, including vascular smooth muscle cells (VSMCs), activated macrophages and macrophages during late stages of differentiation [12]. We assume that there might be an association between DM and YKL-40 since YKL-40 is a new inflammatory marker. Recently, plenty of studies have explored the relationship of DM and YKL-40. But the conclusions of these studies were inconsistent, which might be associated with the sample sizes, methodology and so forth. The objective of our study is to perform a systematic review and meta-analysis to confirm the relationship between YKL-40 and DM as well as DN.

\section{Materials and methods}

\section{Literature search}

Pubmed, Embase, CNKI and Chinese wanfang databases were searched for eligible studies published before April 2020 using combinations of the following terms: diabetes; YKL-40; HC gp-39. All studies were retrieved by two independent reviewers and disagreements were solved by discussion.

\section{Study selection}

Studies were included in this meta-analysis if they fulfilled the following inclusion criteria: (1) a study involving the role of YKL-40 in DM (or DN) designed as a case-control study or cohort study; (2) the data of serum YKL-40 levels were available (mean/standard deviation or median/range or median/interquartile interval was provided); (3) studies were published in English or Chinese. In case of duplicated data, only the most recent and complete study was included.

A total of 253 studies were identified in the initial search. Of these, 206 studies were excluded after screening on titles and abstracts. Full-text reading was performed only for 47 potential studies and details of the searches were shown in the flow chart (Fig. 1). Two publications $[13,14]$, written by the same authors, reported same population, so only the study [13] with more participants was included in our meta-analysis. Finally, 25 studies $[13,15-38]$ that met the inclusion criteria were included in this systematic review. And all the included studies are case-control studies. Of these, 14 studies were written in English and others were written in Chinese.

\section{Data extraction and statistical analysis}

Some of the included studies provided YKL-40 concentration by median and range (or interquartile interval), which were converted to mean (SD) by estimation methods [39]. The statistical software $\mathrm{R}$ was used during the data estimation.

Standardized mean differences (SMD) with 95\% confidence interval $(\mathrm{CI})$ was calculated to compare the levels of serum YKL-40 in the DM (or DN) patients with the levels in healthy controls $(\mathrm{P}<0.05$ was considered statistically significant). The between-study heterogeneity was assessed by chi-square statistic and quantified by I-squared $\left(\mathrm{I}^{2}\right)$. $\mathrm{I}^{2}$ values of $25 \%, 50 \%$ and $70 \%$ were considered as low, moderate and high heterogeneity, respectively [40]. The fixed-effects model was applied if $\mathrm{I}^{2}<50 \%$. Otherwise, the random-effects model was used. If a notable heterogeneity existed, the Galbraith plot was used to detect potential sources of heterogeneity [41]. Additionally, subgroup analyses were applied according to region, age and type of DM. To assess the stability of results, sensitivity analysis was performed by sequential omission of individual studies. Egger's test and funnel plot were used to evaluate the presence of potential publication bias, and $\mathrm{P}<0.05$ was considered to represent statistically significant publication bias [42]. All statistical analyses were performed with STATA 12.0 software.

\section{Results}

\section{Characteristic of included studies}

Totally, 25 studies involving 2498 DM patients and 1424 healthy controls were included in our meta-analysis. Of these 25 studies, 12 were conducted for the different serum levels of YKL-40 between DM patients and healthy controls, 5 were analyzed for YKL-40 levels between GDM patients and healthy controls, and 8 were detected for YKL-40 levels between DM patients with different degree of albuminuria and healthy controls. The characteristics of the included publications are shown in Table 1.

\section{Data analysis \\ Association between serum YKL-40 levels and DM}

Totally, 12 studies showed an association between the serum YKL-40 levels and DM. The meta-analysis results indicated that the serum YKL-40 levels were significantly higher in DM patients compared with healthy controls ( $\mathrm{SMD}=1.62,95 \% \mathrm{CI} 1.08$ to $2.25, \mathrm{P}=0.000$ ) (Fig. 2). The Galbraith plot was used because of the notable heterogeneity. But the major source of heterogeneity could not be 
Studies identified through database search

$(N=253)$

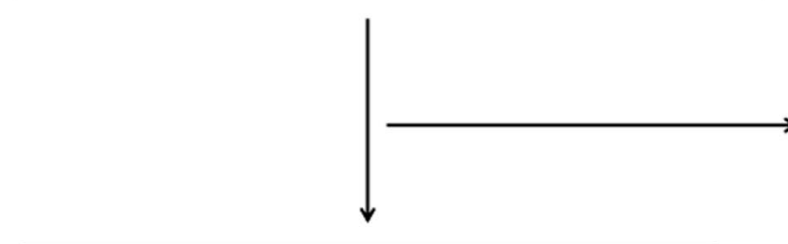

Potentially relevant studies for further

$$
\text { analysis ( } N=47 \text { ) }
$$

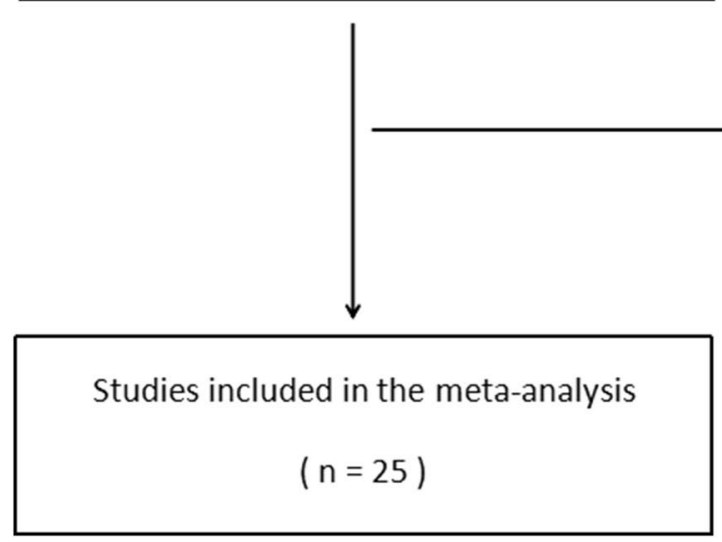

Fig. 1 Flowchart of study selection
Studies excluded based on the

titles and abstracts ( $n=206$ )

Studies excluded, with irrelevant to the $\operatorname{aim}(n=3)$

Duplicate studies $(n=18)$

Data was unable to calculate $\operatorname{SMD}(n=1)$

found since too many of the studies were outliers (Fig. 3). Furthermore, subgroup analyses by type of DM (supplementary material), region and age showed that YKL40 levels were still higher in DM patients than those in healthy controls. The value of $\mathrm{I}^{2}$ remained high in various subgroups, with the exception of one subgroup for studies based on population of Asia.

\section{Association between serum YKL-40 levels and GDM}

Owing to significant heterogeneity, we used the randomeffects model. The pooled SMD was 2.85 (95\% CI 1.01 to $4.70, P=0.002$ ), which indicated that the serum YKL-40 concentrations were significantly higher in GDM patients compared with healthy pregnancies (Fig. 4). The source of heterogeneity was hard to be found by the Galbraith plot because the studies were too dispersive. However, when performing sensitivity analysis by sequential omission of individual studies, YKL-40 was not associated with GDM when the article by XunShengli et al. [29] was removed. The pooled SMD was 0.64 (95\% CI -0.28 to 1.56) $(\mathrm{P}>0.05)$.

\section{Association between serum YKL-40 levels and albuminuria in DM patients}

There were 7, 8 and 7 studies analyzing the relationship between serum YKL-40 levels and normoalbuminuria, microalbuminuria and macroalbuminuria, respectively. The forest plot with a random-effects model showed that DM patients with different degree of albuminuria had significantly higher levels of YKL-40 compared with healthy controls (normoalbuminuria: $\mathrm{SMD}=1.58$, 95\% CI 0.59 to $2.56, \mathrm{P}=0.002$; microalbuminuria: $\mathrm{SMD}=2.57,95 \% \mathrm{CI} 0.92$ to $4.22, \mathrm{P}=0.002$; macroalbuminuria: $\mathrm{SMD}=2.69,95 \% \mathrm{CI} 1.40$ to $3.98, \mathrm{P}=0.000$ ). The Galbraith plot was applied to detect the potential source of heterogeneity. However, we could not find the possible source of heterogeneity because it plotted too many studies as the outliers. In addition, we conducted subgroup analyses by region and type of DM. 
Table 1 Characteristics of the studies included in this meta-analysis

\begin{tabular}{|c|c|c|c|c|c|c|c|c|c|}
\hline Study & Region & Year & $\begin{array}{l}\text { Type } \\
\text { of DM }\end{array}$ & $\begin{array}{l}\text { No. of DM } \\
\text { patients }\end{array}$ & $\begin{array}{l}\text { No. } \\
\text { of healthy } \\
\text { controls }\end{array}$ & Mean age of DM patients & $\begin{array}{l}\text { Mean age } \\
\text { of healthy } \\
\text { controls }\end{array}$ & Diagnosis criteria & Method \\
\hline $\begin{array}{l}\text { Jian Li et al. } \\
\text { [15] }\end{array}$ & China & 2015 & GDM & 35 & 43 & $29.3 \pm 3.1$ & $30.6 \pm 3.8$ & ADA 2012 & ELISA (Quidel, USA) \\
\hline $\begin{array}{c}\text { Rathcke } \\
\text { et al. } \\
\text { [16] }\end{array}$ & Denmark & 2005 & T2DM & 87 & 158 & $54.2(40-70)^{a}$ & NA & $\begin{array}{l}\text { National Diabetes } \\
\text { Data Group } 1979\end{array}$ & ELISA (Quidel, USA) \\
\hline $\begin{array}{l}\text { Thomsen } \\
\text { et al. } \\
\text { [17] }\end{array}$ & Denmark & 2010 & T2DM & 45 & 20 & $54(41-73)^{b}$ & $50(34-66)^{b}$ & NA & ELISA (Quidel, USA) \\
\hline $\begin{array}{l}\text { Schaller } \\
\text { et al. } \\
{[18]}\end{array}$ & Austria & 2010 & GDM & 28 & 30 & $33 \pm 6$ & $33 \pm 4$ & $\begin{array}{l}\text { ADA criteria for } \\
\text { GDM } 2004\end{array}$ & ELISA (Quidel, USA) \\
\hline $\begin{array}{l}\text { Sakamoto } \\
\text { et al. } \\
{[19]}\end{array}$ & Japan & 2013 & T1DM & 131 & 97 & $24.7 \pm 5.9$ & $25.5 \pm 2.7$ & NA & ELISA (Quidel, USA) \\
\hline $\begin{array}{l}\text { Rinnov } \\
\text { et al. } \\
\text { [20] }\end{array}$ & Denmark & 2015 & GDM & 10 & 8 & $31.1 \pm 5.6$ & $28.1 \pm 1.8$ & $\begin{array}{l}\text { OGTT } 2 \mathrm{~h} \\
\text { GLU } \geq 9.0 \mathrm{mM}\end{array}$ & ELISA (Quidel, USA) \\
\hline $\begin{array}{l}\text { Abd El } \\
\text { Dayem } \\
\text { et al. } \\
\text { [21] }\end{array}$ & Egypt & 2015 & T1DM & 62 & 30 & $16.32 \pm 1.52$ & $16.13 \pm 2.63$ & NA & ELISA (Quidel, USA) \\
\hline $\begin{array}{l}\text { Shiasi et al. } \\
{[22]}\end{array}$ & Iran & 2017 & T1DM & 49 & 43 & $12.20 \pm 3.86$ & $10.95 \pm 3.83$ & ADA & ELISA (Quidel, USA) \\
\hline $\begin{array}{l}\text { Rekha } \\
\text { Kumari } \\
\text { et al. } \\
\text { [23] }\end{array}$ & India & 2015 & T2DM & 30 & 30 & $44.4 \pm 2.7$ & $45.95 \pm 3.4$ & NA & ELISA \\
\hline $\begin{array}{l}\text { Song Wei } \\
\text { et al. } \\
\text { [24] }\end{array}$ & China & 2015 & T2DM & 210 & 210 & $58.29 \pm 5.94$ & $59.98 \pm 7.53$ & NA & ELISA (Quidel, USA) \\
\hline $\begin{array}{l}\text { Ye Kejun } \\
\text { et al. } \\
\text { [25] }\end{array}$ & China & 2016 & GDM & 50 & 50 & $27.2 \pm 3.4$ & $28.6 \pm 3.8$ & ADA 2005 & ELISA \\
\hline $\begin{array}{l}\text { Chen } \\
\text { Qingfu } \\
\text { et al. } \\
\text { [26] }\end{array}$ & China & 2014 & $\mathrm{~T} 2 \mathrm{DM}$ & 48 & 45 & NA & $48.1 \pm 13.7$ & WHO 1999 & ELISA (Quidel, USA) \\
\hline $\begin{array}{l}\text { Li Peng } \\
\text { et al. } \\
\text { [27] }\end{array}$ & China & 2011 & $\mathrm{~T} 2 \mathrm{DM}$ & 41 & 40 & $54.61 \pm 12.37$ & $42.8 \pm 13.52$ & NA & $\begin{array}{l}\text { ELISA } \\
\text { (Becton,Dickinson } \\
\text { and Company, USA) }\end{array}$ \\
\hline $\begin{array}{l}\text { Lin Lijun } \\
\text { et al. } \\
\text { [28] }\end{array}$ & China & 2019 & $\mathrm{~T} 2 \mathrm{DM}$ & 42 & 40 & NA & NA & NA & ELISA \\
\hline $\begin{array}{l}\text { Xun } \\
\text { Shengli } \\
\text { et al. } \\
\text { [29] }\end{array}$ & China & 2017 & GDM & 60 & 20 & $27.85 \pm 4.48$ & $26.82 \pm 3.10$ & $\begin{array}{l}\text { Obstetrics and } \\
\text { gynecology [M] }\end{array}$ & ELISA \\
\hline $\begin{array}{l}\text { Yu Yeye } \\
\text { et al. } \\
\text { [30] }\end{array}$ & China & 2018 & T2DM & 60 & 60 & $46.48 \pm 11.54$ & $47.83 \pm 9.68$ & ADA 2007 & ELISA \\
\hline $\begin{array}{l}\text { Ren Lijue } \\
\text { et al. } \\
\text { [31] }\end{array}$ & China & 2019 & $\mathrm{~T} 2 \mathrm{DM}$ & 30 & 30 & $57.20 \pm 10.30$ & $54.5 \pm 10.44$ & WHO 1999 & ELISA \\
\hline $\begin{array}{c}\text { Rathcke } \\
\text { et al. } \\
\text { [32] }\end{array}$ & Denmark & 2009 & T1DM & $58^{A} / 46^{B} / 45^{C}$ & 55 & $\begin{array}{l}55.6 \pm 10.8^{A} / 54 \pm 11.1^{B} / 4 \\
\quad 9 \pm 9.6^{C}\end{array}$ & $50.5 \pm 10.9$ & NA & ELISA (Quidel, USA) \\
\hline $\begin{array}{l}\text { Røndbjerg } \\
\text { et al. } \\
\text { [33] }\end{array}$ & Denmark & 2011 & T2DM & $49^{A} / 35^{B} / 21^{C}$ & 20 & $\begin{array}{l}61.3 \pm 12.0^{A} / 60.1 \pm 11.7^{B} / 6 \\
4 \pm 13.1^{C}\end{array}$ & $57.1 \pm 7.2$ & NA & ELISA (Quidel, USA) \\
\hline $\begin{array}{l}\text { Lee et al. } \\
\quad[34]\end{array}$ & $\begin{array}{l}\text { South } \\
\text { Korea }\end{array}$ & 2012 & T2DM & $25^{A} / 25^{B} / 25^{C}$ & 22 & $\begin{array}{l}55.6 \pm 11.1^{A} / 57.0 \pm 11.6^{B} / 5 \\
\quad 6.0 \pm 9.8^{C}\end{array}$ & $52.4 \pm 5.8$ & NA & ELISA \\
\hline
\end{tabular}


Table 1 (continued)

\begin{tabular}{|c|c|c|c|c|c|c|c|c|c|}
\hline Study & Region & Year & $\begin{array}{l}\text { Type } \\
\text { of DM }\end{array}$ & $\begin{array}{l}\text { No. of DM } \\
\text { patients }\end{array}$ & $\begin{array}{l}\text { No. } \\
\text { of healthy } \\
\text { controls }\end{array}$ & Mean age of DM patients & $\begin{array}{l}\text { Mean age } \\
\text { of healthy } \\
\text { controls }\end{array}$ & Diagnosis criteria & Method \\
\hline $\begin{array}{l}\text { Han et al. } \\
\text { [13] }\end{array}$ & China & 2015 & T2DM & $260^{A} / 246^{B} / 232^{C}$ & 210 & $\begin{array}{l}52.83 \pm 4.30^{\mathrm{A}} / 53.93 \pm 4.56^{\mathrm{B}} / \\
53.93 \pm 4.22^{\mathrm{C}}\end{array}$ & $53.40 \pm 4.28$ & ADA 2007 & $\begin{array}{l}\text { ELISA (Bio-Technology } \\
\text { Co. Ltd., USA) }\end{array}$ \\
\hline $\begin{array}{l}\text { Umapathy } \\
\text { et al. } \\
\text { [35] }\end{array}$ & India & 2018 & T2DM & $81^{A} / 73^{B} / 69^{C}$ & 83 & $\begin{array}{l}54.07 \pm 11.09^{\mathrm{A}} / 55.1 \pm 10.9^{\mathrm{B} /} \\
57.39 \pm 5.39^{\mathrm{C}}\end{array}$ & $52.59 \pm 12.9$ & NA & $\begin{array}{l}\text { a multiplex bead- } \\
\text { based assay system } \\
\text { (Bio-Rad, Hercules, } \\
\text { California, USA) }\end{array}$ \\
\hline $\begin{array}{l}\text { Zhu Hui- } \\
\text { jing et al. } \\
{[36]}\end{array}$ & China & 2015 & $\mathrm{~T} 2 \mathrm{DM}$ & $23^{A} / 24^{B} / 23^{C}$ & 20 & $\begin{array}{l}63.00 \pm 13.76^{A} / 65.33 \pm 9.13^{B} \\
\quad / 66.35 \pm 7.84^{C}\end{array}$ & $62.0 \pm 11.16$ & ADA 2007 & ELISA \\
\hline $\begin{array}{l}\text { Wang } \\
\text { Huan } \\
\text { et al. } \\
\text { [37] }\end{array}$ & China & 2015 & $\mathrm{~T} 2 \mathrm{DM}$ & $21^{B} / 39^{C}$ & 30 & NA & $68 \pm 8$ & NA & ELISA (Quidel, USA) \\
\hline $\begin{array}{l}\text { Yu Zhixuan } \\
\text { et al. } \\
\text { [38] }\end{array}$ & China & 2017 & T2DM & $30^{A} / 30^{B}$ & 30 & NA & $55.45 \pm 7.36$ & NA & ELISA \\
\hline \multicolumn{10}{|c|}{$\begin{array}{l}\text { T1DM type } 1 \text { diabetes mellitus, T2DM type } 2 \text { diabetes mellitus, GDM gestatio } \\
\text { Organization, ELISA enzyme linked immunosorbent assay, NA Not available }\end{array}$} \\
\hline \multicolumn{10}{|c|}{ A DM patients with normoalbuminuria, } \\
\hline \multicolumn{10}{|c|}{ B DM patients with microalbuminuria } \\
\hline \multicolumn{10}{|c|}{${ }^{C}$ DM patients with macroalbuminuria } \\
\hline \multicolumn{10}{|c|}{ a Mean/range } \\
\hline Median/ra & ange & & & & & & & & \\
\hline
\end{tabular}

The results did not change in various subgroups, and the value of $\mathrm{I}^{2}$ remained high in various subgroups, with the exception of one subgroup for studies based on population of Asia. What's more, serum YKL-40 levels increased with increasing severity of albuminuria among DM patients (microalbuminuria vs normoalbuminuria: $\mathrm{SMD}=1.49,95 \% \mathrm{CI} 0.28$ to $2.71, \mathrm{P}=0.016$; macroalbuminuria vs microalbuminuria: $\mathrm{SMD}=0.93$, $95 \%$ CI 0.34 to $1.52, \mathrm{P}=0.002$ ).

\section{Sensitivity analysis}

We performed a sensitivity analysis by sequential omission of individual studies. When serum YKL-40 levels were compared between DM patients and heathy controls as well as DM patients with different degree of albuminuria and healthy controls, the pooled SMD were not materially altered. However, YKL-40 was not associated with GDM when the study by XunShengli et al.[29] was deleted.

\section{Publication bias}

Funnel plot and Egger's test were conducted to evaluate the potential publication bias. There was no obvious funnel plot asymmetry and all the P values of the Egger's tests were over 0.05 , suggesting that publication bias was not evident in our meta-analysis.

\section{Discussion}

To our knowledge, this is the first systematic review and meta-analysis to assess the relationship between YKL-40 and DM. Our study indicate that DM patients have a significantly higher level of YKL-40 compared with healthy controls. In addition, YKL-40 concentrations are higher in DM patients with different degree of albuminuria than those in healthy controls and increase with increasing severity of albuminuria.

Diabetes mellitus is a complex group of metabolic diseases characterized by hyperglycemia and is a major public health problem throughout the world. Both of T1DM and T2DM are genetic predisposition and influenced by environment. The genes responsible for T1DM are carried on chromosome $6 \mathrm{p} 21$ and take control of the immune system [43]. Many genes are relative to T2DM, but most of them have not been identified. Recently, inflammation is involved in the pathogenesis of DM. Previous study have found that long-term T1DM patients have a significantly higher level of CRP than healthy controls [44]. Besides, CRP is also higher in T2DM patients than in healthy controls [45]. But the role of inflammatory processes seems to be more important in the development of T2DM than T1DM. Some studies have indicated that inflammatory markers such as CRP and IL-6 are increased in healthy population who later developed T2DM [46, 47], suggesting that inflammation may occur ahead of the diagnosis of T2DM. Insulin resistance 


\begin{tabular}{|c|c|c|c|c|}
\hline Study & & & & $\%$ \\
\hline ID & & SMD & $(95 \% \mathrm{CI})$ & Weight \\
\hline Rathcke CN & & 1.00 & $(0.72$, & $1 . 2 8 \longdiv { 8 . 7 3 }$ \\
\hline Thomsen SB & $\longrightarrow$ & 0.55 & $(0.02$, & $1 . 0 9 \longdiv { 8 . 2 0 }$ \\
\hline Sakamoto $\mathrm{F}$ & $\rightarrow$ & 0.94 & $(0.66$ & $1 . 2 1 \longdiv { 8 . 7 3 }$ \\
\hline Abd El Dayem SM & $x$ & 0.77 & $(0.32$ & $1.22) 8.41$ \\
\hline Shiasi K & & 2.15 & (1.63, & $2 . 6 6 \longdiv { 8 . 2 5 }$ \\
\hline Rekha Kumari D & & 3.34 & $(2.55$ & $4 . 1 4 \longdiv { 7 . 4 7 }$ \\
\hline Song Wei & & 3.04 & $(2.76$ & $3 . 3 3 \longdiv { 8 . 7 2 }$ \\
\hline Chen Qingfu & & 1.96 & $(1.46$ & $2 . 4 5 \longdiv { 8 . 3 0 }$ \\
\hline Li Peng & & 1.13 & $(0.66$ & $1 . 6 0 \longdiv { 8 . 3 6 }$ \\
\hline Lin Lijun & & 2.49 & $(1.91$ & $3 . 0 7 \longdiv { 8 . 0 9 }$ \\
\hline Yu Yeye & & 1.50 & (1.09) & $1 . 9 0 \longdiv { 8 . 5 0 }$ \\
\hline Ren Lijue & $\rightarrow$ & 0.71 & (0.19, & $1 . 2 4 \longdiv { 8 . 2 3 }$ \\
\hline Overall (I-squared $=95.0 \%, p=0.000)$ & & 1.62 & $(1.08$, & $2.15) 100.00$ \\
\hline NOTE: Weights are from random effects ar & alysis & & & \\
\hline
\end{tabular}

Fig. 2 Forest plot of YKL-40 levels in DM patienst compared with healthy controls

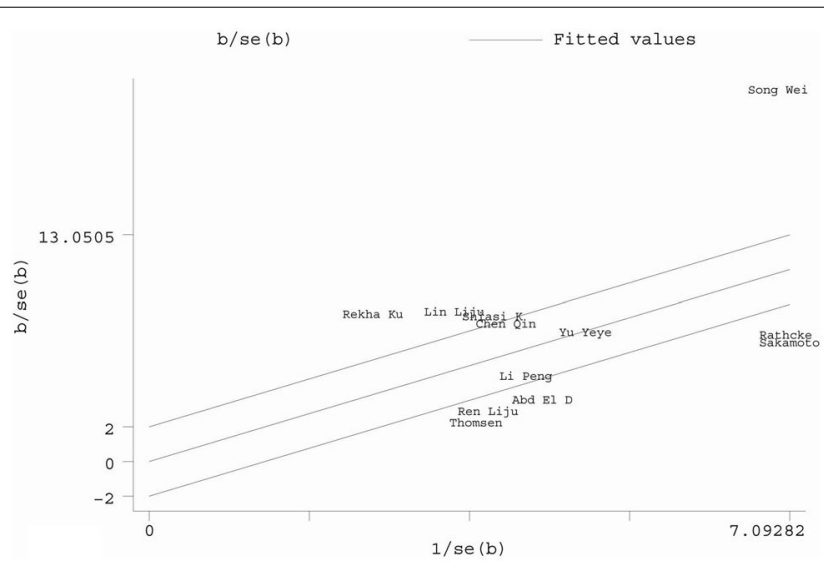

Fig. 3 Galbraith plot of YKL-40 levels in DM patients compared with healthy controls 


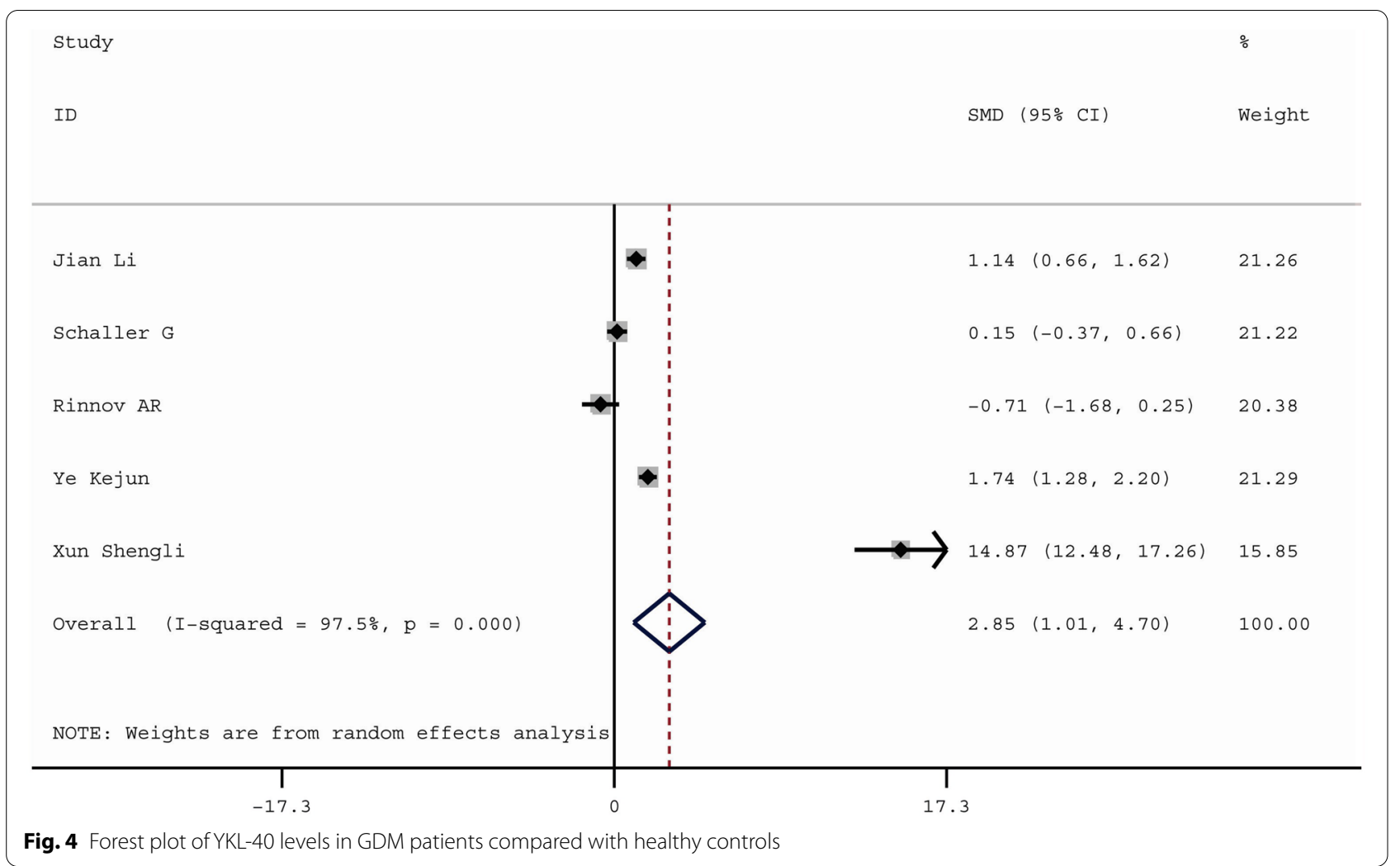

is common in T2DM and most patients with T2DM are obese, which itself can cause some degree of insulin resistance. Obesity, especially activation of adipose tissue, might enhance the release of inflammatory factors [48].

YKL-40, a new inflammatory marker, is related to both acute and chronic inflammation. Some studies have showed that levels of YKL-40 are increased in patients with purulent menigitis, rheumatoid arthritis, osteoarthritis, systemic lupus erythematosus and inflammatory bowel disease $[49,50]$. Obesity is related to increased macrophage infiltration of adipose tissue and plays an important role in the development of insulin resistance [51]. YKL-40 is possibly with relation to the insulin resistance based on the macrophage infiltration and adipose tissue [12]. All the evidences above indicate that YKL40 might have a relationship with DM. And our study, with more strong power, confirm that patients with DM have significantly higher levels of YKL-40 compared with healthy controls. What's more, some studies have showed that inflammation is associated with hyperglycemia. And inflammatory markers, including IL- 6 , IL-1ßand TNF- $\alpha$, are often found increased in DM patients, whose glucose in poorly controlled $[7,8]$. The great majority of studies (22 studies) included in our meta-analysis provided data of HhA1c values. In some studies, HbA1c values were higher than upper limits of normal range, but 5 studies $[23-25,27,30]$ showed that YKL-40 levels are positively correlated with HbA1c, while 3 studies [19, 21, 22] did not show any correlation. Therefore, although YKL- 40 is also an inflammatory cytokine, the relationship between hyperglycemia and YKL-40 needs to be confirmed.

The prevalence of GDM is increasing all over the world, of which the exact pathogenesis is not quietly understood. But many findings have showed that GDM patients have a trend of developing to T2MD. There are also some studies indicating that insulin resistance is an important pathophysiological contributor of GDM $[52,53]$. Our present study find that the serum YKL-40 levels are higher in GDM patients than in healthy pregnancies. However, when the study by XunShengli et al. [29] is deleted during sensitivity analysis, YKL-40 is not associated with GDM. In the study by XunShengli et al., Enzyme Linked Immunosorbent Assay (ELISA) without details about the machine and reagents was used to measure the serum YKL-40 levels and the unit was pg/ $\mathrm{ml}$ ( $\mathrm{ng} / \mathrm{ml}$ was used in other included studies). Compared with other included studies, the values of YKL-40 in this study were extremely small, which may have a strong contribution to obtain statistical significance. Anyway, the association between YKL-40 and GDM remains to be further confirmed by larger number of studies. 
There are three types of complications of DM, including macrovascular, microvascular and neurologic. Kidney is the most obviously involved organ in microvascular complications and urinary albumin is a sign of DN. Some studies have found a high prevalence of microalbuminuria in DM patients $[54,55]$. The pathogenesis of $\mathrm{DN}$ is multiple, and inflammation seems to be a major mechanism. Interaction of metabolism and hemodynamics, which activates many inflammatory molecules and pathway, results in DN $[56,57]$. In addition, vascular endothelial dysfunction is a major factor in the pathogenesis of diabetic micro-angiopathy [58]. And YKL-40 is expressed in the development of endothelial dysfunction, during the differentiation and maturation of $\mathrm{CD} 14+$ monocytes to CD14-, CD16+ macrophages [12]. YKL-40, as a marker of inflammation and endothelial dysfunction, is found associated with albuminuria in T2DM patients [59, 60]. Consistent with previous studies, we find that the levels of YKL-40 are higher in DM patients with different degree of albuminuria compared with healthy controls and the levels of YKL- 40 are positively related with the severe degree of albuminuria.

\section{Study limitations}

Some limitations of this study should be mentioned. First, the heterogeneity is high and the major causes are not found by the Galbraith plot and subgroup analyses. Second, the criteria of normoalbuminuria, microalbuminuria and macroalbuminuria were different among the studies included in this meta-analysis. In some studies, urinary albumin excretion rate was used as classification criterion, but in others, albumin/creatinine was used. As thus, the results of our study are not stable enough.

\section{Conclusion}

In summary, our current meta-analysis demonstrates that serum level of YKL-40 is increased in DM and positively associated with the severe degree of albuminuria. Therefore, we suggest that YKL-40 could be considered to be detected, along with other inflammatory markers, if $\mathrm{DM}$, especially $\mathrm{DN}$, is suspected.

\section{Acknowledgements}

Not applicable.

\section{Authors' contributions}

All authors have contributed equally. All authors read and approved the final manuscript.

\section{Funding}

The authors have received no funding support regarding this study.

\section{Availability of data and materials}

The datasets used and/or analysed during the current study are available from the corresponding author on reasonable request.
Ethics approval and consent to participate Not applicable.

\section{Consent for publication}

If the manuscript is accepted, we approve it for publication in Diabetology \& Metabolic Syndrome.

\section{Competing interests}

None of the authors have any competing interests.

Received: 26 August 2020 Accepted: 6 January 2021

Published online: 15 January 2021

\section{References}

1. American Diabetes Association. Diagnosis and classification of diabetes mellitus. Diabetes Care. 2013;36(Suppl 1):S67-74.

2. National Kidney Foundation. KDOQI clinical practice guideline for diabetes and CKD: 2012 update. Am J Kidney Dis. 2012;60:850-86.

3. Papadopoulou-Marketou N, Chrousos GP, Kanaka-Gantenbein C. Diabetic nephropathy in type 1 diabetes: a review of early natural history, pathogenesis, and diagnosis. Diabetes Metabol Res Rev. 2017;33:e2841.

4. Papadopoulou-Marketou N, Paschou SA, Marketos N, Adamidi S, Adamidis S, Kanaka-Gantenbein C. Diabetic nephropathy in type 1 diabetes. Minerva Med. 2018;109:218-28.

5. Lontchi-Yimagou E, Sobngwi E, Matsha TE, Kengne AP. Diabetes mellitus and inflammation. Curr DiabRep. 2013;13:435-44.

6. Halim M, Halim A. The effects of inflammation, aging and oxidative stress on the pathogenesis of diabetes mellitus (type 2 diabetes). Diabetes Metabol Syndrome. 2019;13:1165-72.

7. Kumar P, Raman T, Swain MM, Mishra R, Pal A. Hyperglycemia-induced oxidative-nitrosative stress induces inflammation and neurodegeneration via augmented tuberous sclerosis complex-2 (TSC-2) activation in neuronal cells. Mol Neurobiol. 2017;54:238-54.

8. Chang SC, Yang WV. Hyperglycemia, tumorigenesis, and chronic inflammation. Critic Rev oncol hematol. 2016;108:146-53.

9. Volck B, Price PA, Johansen JS, Sorensen O, Benfield TL, Nielsen HJ, et al. YKL-40, a mammalian member of the chitinase family, is a matrix protein of specific granules in human neutrophils. Proc Assoc Am Physicians. 1998;110:351-60.

10. Rehli M, Niller HH, Ammon C, Langmann S, Schwarzfischer L, Andreesen $\mathrm{R}$, et al. Transcriptional regulation of $\mathrm{CHI} 3 \mathrm{~L} 1$, a marker gene for late stages of macrophage differentiation. J Biol Chem. 2003;278:44058-67.

11. Baeten D, Boots AM, Steenbakkers PG, Elewaut D, Bos E, Verheijden GF, et al. Human cartilage gp-39+, CD16+ monocytes in peripheral blood and synovium: correlation with joint destruction in rheumatoid arthritis. Arthritis Rheum. 2000;43:1233-43.

12. Rathcke $C N$, Vestergaard $H$. YKL-40, a new inflammatory marker with relation to insulin resistance and with a role in endothelial dysfunction and atherosclerosis. Inflammat Res. 2006:55:221-7.

13. Han JY, Ma XY, Yu LJ, Shao Y, Wang QY. Correlation between serum YKL-40 levels and albuminuria in type 2 diabetes. Genet Mol Res. 2015;14:18596-603.

14. Han JY, Shao Y, Wang QY. The correlation of serum YKL-40 and albuminuria in type 2 diabetes. Chinese J Endocrinol Metabol. 2014;30:225-7.

15. Li J, Niu G, Wang H, Wang K, Huang B, Li M. Serum YKL-40 levels in gestational diabetes mellitus. Gynecol Endocrinol. 2016;32:412-5.

16. Rathcke CN, Johansen JS, Vestergaard H. YKL-40, a biomarker of inflammation, is elevated in patients with type 2 diabetes and is related to insulin resistance. Inflammat Res. 2006;55:53-9.

17. Thomsen SB, Rathcke CN, Zerahn B, Vestergaard H. Increased levels of the calcification marker matrix Gla Protein and the inflammatory markers YKL40 and CRP in patients with type 2 diabetes and ischemic heart disease. Cardiovasc Diabetol. 2010;9:86.

18. Schaller G, Brix JM, Placher-Sorko G, Hollerl F, Schernthaner GH, Schernthaner G. YKL-40 concentrations are not elevated in gestational diabetes. Eur J Clin Invest. 2010:40:339-43.

19. Sakamoto F, Katakami N, Kaneto H, Yasuda T, Takahara M, Miyashita K, et al. Association of serum YKL-40 levels with urinary albumin excretion 
rate in young Japanese patients with type 1 diabetes mellitus. Endocr J. 2013;60:73-9.

20. Rinnov AR, Rathcke CN, Bonde L, Vilsboll T, Knop FK. Plasma YKL-40 during pregnancy and gestational diabetes mellitus. J Reprod Immunol. 2015;112:68-72.

21. Abd El Dayem SM, Battah AA, El Shehaby A, Abd Allah N. Assessment of human cartilage glycoprotein 39 (YKL-40), preptin, and nitric oxide in adolescent patients with type 1 diabetes and its relation to cardiorenal affection. J Pediat Endocrinol Metabol. 2015;28:309-14.

22. Shiasi K, Talebian F, Khamechi SP, Nikoueinejad H, Sehat M, Azarbad Z, et al. Evaluation of YKL-40 serum level in patients with type 1 diabetes and its correlation with their metabolic and renal conditions. NephroUrol Month. 2017; 9

23. Rekha Kumari D, Farid Babu M, Balu MK. Human cartilage glycoprotein 39 (YKL-40): a View in type 2 diabetes mellitus. Int J Pharm Sci Res. 2015;6(11):4852-6.

24. Song W, Zhang K, Dong LP, Lu W, Li CG, Luan J. Association between YKL40 and type 2 diabetic microangiopathy. Chinese J Clin. 2015;9:3214-8.

25. Ye KJ, Hao Q, Dai J, Ye XJ. Association between YKL-40 and gestational diabetes mellitus. China medical herald. 2016;13:75-8.

26. Chen $\mathrm{QF}, \mathrm{Yi}$ ZG, Guo WA. Association between YKL-40 and type 2 diabetes as well as lower extremity atherosclerosis. Guide China Med. 2014;12:78-9.

27. Li P, Gao JD, Zhang HL, Ma SH, Du CG. Expression of YKL-40 and Chemerin in chronic complications of type 2 diabetes mellitus. Modern Med Health. 2011;27:2300-2.

28. Lin LJ, Fan PY, Yao YL, Luo W, Jiang YP, Song K, et al. The relationship between serum YKL-40 and type 2 diabetic retinopathy and diabetic nephropathy. Chinese High Altit Med Biol. 2019;40(118-21):129.

29. Xun SL, Hu JJ, Chen J, Zhang LL, Lu HM, Kong X. Expression and significance of YKL-40 in maternal blood and umbilical cord blood serum and placenta in patients with gestational diabetes mellitus. China Foreign Med Treat. 2017:10:52-5.

30. Yu YY, Shi X, Pan JQ, Shi WW, Tan LY, Yu XJ. Study on the correlation between serum A-FABP and YKL-40 levels and insulin resistance in newly diagnosed T2DM patients. J Liaoning Med Univ. 2018;39:17-21.

31. Ren $L Y$, Wang $Y Z$, Wei $C Y$, Liu Y, Zheng LM. Correlation between levels of lipoprotein-associated phospholipase A2 and chitinase 3-like protein 1 with diabetes retinopathy in type 2 diabetes mellitus. China Health Standard Managem. 2019;20:27-30.

32. Rathcke CN, Persson F, Tarnow L, Rossing P, Vestergaard H. YKL-40, a marker of inflammation and endothelial dysfunction, is elevated in patients with type 1 diabetes and increases with levels of albuminuria. Diabetes Care. 2009;32:323-8.

33. Rondbjerg AK, Omerovic E, Vestergaard H. YKL-40 levels are independently associated with albuminuria in type 2 diabetes. Cardiovascu Diabetol. 2011;10:54.

34. Lee JH, Kim SS, Kim IJ, Song SH, Kim YK, In Kim J, et al. Clinical implication of plasma and urine YKL-40, as a proinflammatory biomarker, on early stage of nephropathy in type 2 diabetic patients. J Diabetes Complicat. 2012;26:308-12.

35. Umapathy D, Dornadula S, Krishnamoorthy E, Mariappanadar V, Viswanathan V, Ramkumar KM. YKL-40: A biomarker for early nephropathy in type 2 diabetic patients and its association with inflammatory cytokines. Immunobiology. 2018;223:718-27.

36. Zhu HJ, Yang MM, Cheng L, Zhu X, Cheng XB. The changes and clinical significance of serum YKL-40 level in type 2 diabetic patients with chronic kidney disease. Chinese J Diabetes. 2015;23:720-2.

37. Wang $\mathrm{H}$, Cui $\mathrm{K}, \mathrm{Xu}$ K, Fang XX. Relationship between serum YKL-40 and atherosclerosis in patients with type 2 diabetic nephropathy. Chinese J Integrat Tradit Western Nephrol. 2015;16:57-8.

38. Yu ZX, Wang YZ. YKL-40 and MPV in the clinical value of early diabetic nephropathy. Chinese J Clin. 2017;11:1110-3.

39. Wan X, Wang W, Liu J, Tong T. Estimating the sample mean and standard deviation from the sample size, median, range and/or interquartile range. BMC Med Res Methodol. 2014;14:135.
40. Higgins JP, Thompson SG, Deeks JJ, Altman DG. Measuring inconsistency in meta-analyses. BMJ. 2003;327:557-60.

41. Galbraith RF. A note on graphical presentation of estimated odds ratios from several clinical trials. Stat Med. 1988;7:889-94.

42. Egger M, Davey Smith G, Schneider M, Minder C. Bias in meta-analysis detected by a simple, graphical test. BMJ. 1997;315:629-34.

43. Morwessel NJ. The genetic basis of diabetes mellitus. AACN Clin Issues. 1998;9:539-54.

44. Treszl A, Szereday L, Doria A, King GL, Orban T. Elevated C-reactive protein levels do not correspond to autoimmunity in type 1 diabetes. Diabetes Care. 2004;27:2769-70.

45. Temelkova-Kurktschiev T, Henkel E, Koehler C, Karrei K, Hanefeld M. Subclinical inflammation in newly detected Type II diabetes and impaired glucose tolerance. Diabetologia. 2002;45:151.

46. Vozarova B, Weyer C, Lindsay RS, Pratley RE, Bogardus C, Tataranni PA. High white blood cell count is associated with a worsening of insulin sensitivity and predicts the development of type 2 diabetes. Diabetes. 2002:51:455-61.

47. Pradhan AD, Manson JE, Rifai N, Buring JE, Ridker PM. C-reactive protein, interleukin 6, and risk of developing type 2 diabetes mellitus. JAMA. 2001;286:327-34

48. King GL. The role of inflammatory cytokines in diabetes and its complications. J Periodontol. 2008;79:1527-34.

49. Østergaard C, Johansen JS, Benfield T, Price PA, Lundgren JD. YKL-40 is elevated in cerebrospinal fluid from patients with purulent meningitis. Clin Diagn Lab Immunol. 2002;9:598-604.

50. Vos K, Steenbakkers P, Miltenburg AM, Bos E, van Den Heuvel MW, van Hogezand RA, et al. Raised human cartilage glycoprotein-39 plasma levels in patients with rheumatoid arthritis and other inflammatory conditions. Ann Rheum Dis. 2000;59:544-8.

51. Neels JG, Olefsky JM. Inflamed fat: what starts the fire? J Clin Investig. 2006;116:33-5.

52. Catalano PM, Tyzbir ED, Wolfe RR, Calles J, Roman NM, Amini SB, et al. Carbohydrate metabolism during pregnancy in control subjects and women with gestational diabetes. Am J Physiol. 1993;264:E60-7.

53. Catalano PM, Huston L, Amini SB, Kalhan SC. Longitudinal changes in glucose metabolism during pregnancy in obese women with normal glucose tolerance and gestational diabetes mellitus. Am J Obstet Gynecol. 1999;180:903-16.

54. Adler Al, Stevens RJ, Manley SE, Bilous RW, Cull CA, Holman RR. Development and progression of nephropathy in type 2 diabetes: the United Kingdom Prospective Diabetes Study (UKPDS 64). Kidney Int. 2003:63:225-32.

55. Parving $\mathrm{HH}$, Hommel E, Mathiesen E, Skott P, Edsberg B, Bahnsen M, et al. Prevalence of microalbuminuria, arterial hypertension, retinopathy and neuropathy in patients with insulin dependent diabetes. BMJ. 1988;296:156-60.

56. Cooper ME. Interaction of metabolic and haemodynamic factors in mediating experimental diabetic nephropathy. Diabetologia. 2001;44:1957-72.

57. Navarro-Gonzalez JF, Mora-Fernandez C, Muros de Fuentes M, GarciaPerez J. Inflammatory molecules and pathways in the pathogenesis of diabetic nephropathy. Nat Rev Nephrol. 2011;7:327-40.

58. Schalkwijk CG, Stehouwer CD. Vascular complications in diabetes mellitus: the role of endothelial dysfunction. Clin Sci. 2005;109:143-59.

59. Brix JM, Hollerl F, Koppensteiner R, Schernthaner G, Schernthaner GH. YKL-40 in type 2 diabetic patients with different levels of albuminuria. Eur J Clin Invest. 2011;41:589-96.

60. Yasuda T, Kaneto H, Katakami N, Kuroda A, Matsuoka TA, Yamasaki Y, et al. YKL-40, a new biomarker of endothelial dysfunction, is independently associated with albuminuria in type 2 diabetic patients. Diabetes Res Clin Pract. 2011;91:e50-2.

\section{Publisher's Note}

Springer Nature remains neutral with regard to jurisdictional claims in published maps and institutional affiliations. 